\title{
The Compatibility of Model Eliciting Activities of Secondary School Teacher Candidates with Design Principles
}

\author{
Aysun Nüket ELÇİ *1 (i) \\ ${ }^{1}$ Manisa Celal Bayar University, Faculty of Education, Manisa, Turkey, aysunnuketelci@hotmail.com \\ * Corresponding Author: aysunnuketelci@hotmail.com
}

\begin{tabular}{|c|c|}
\hline Article Info & Abstract \\
\hline $\begin{array}{l}\text { Received: } 26 \text { February } 2020 \\
\text { Accepted: } 22 \text { March } 2020\end{array}$ & $\begin{array}{l}\text { The purpose of this study is the investigation of the compatibility of } \\
\text { model eliciting activities of secondary school teacher candidates with } \\
\text { design principles. This study was conducted in the scope of } \\
\text { Mathematical Modelling course with the students who were the } \\
\text { secondary school mathematics teacher candidates. The participants of } \\
\text { this case study were thirty-nine mathematics teacher candidates who } \\
\text { worked in eight groups. The data of this study consisted of eight model }\end{array}$ \\
\hline $\begin{array}{l}\text { Keywords: Mathematical modelling, } \\
\text { model eliciting activities, principles } \\
\text { of model eliciting activities, } \\
\text { secondary school mathematics } \\
\text { teacher candidates } \\
\text { doi } \mathbf{1 0 . 1 8 0 0 9 / j c e r . 6 9 5 2 5 3}\end{array}$ & $\begin{array}{l}\text { eliciting activities which were created within the eight groups and their } \\
\text { analysis. The activities created by the groups were analyzed by } \\
\text { document analysis method in terms of design principles that were } \\
\text { defined for model eliciting activities. It was concluded that the created } \\
\text { model eliciting activities satisfied the construct share ability and } \\
\text { reusability principle at minimum while they satisfied the reality } \\
\text { principle at maximum. The effective prototype principle could not be } \\
\text { determined. It can be ensured that the secondary school mathematics }\end{array}$ \\
\hline Publication Language: English & $\begin{array}{l}\text { teacher candidates gain more experience by making more } \\
\text { implementations related to model eliciting activities. The } \\
\text { implementation of model eliciting activities in class can be effective in } \\
\text { reducing the modelling deficiencies of secondary school mathematics } \\
\text { teacher candidates. }\end{array}$ \\
\hline CrossMark CC & $\begin{array}{l}\text { To cite this article: Elçi, A. N. (2020). The compatibility of model } \\
\text { eliciting activities of secondary school teacher candidates with design } \\
\text { principles. Journal of Computer and Education Research, } 8 \text { (15), 305-322. } \\
\text { DOI: } 10.18009 \text { /jcer.695253 }\end{array}$ \\
\hline
\end{tabular}

\section{Introduction}

Mathematical modelling in mathematics education attracts the attention of researchers in recent years (eg. Kertil, 2008; Tural-Sönmez, 2017). The revelation of the relations between mathematics and real world by mathematical modelling (Kaiser \& Schwarz, 2006; Tural-Sönmez, 2019), the help of it in gaining the skills needed to solve the real life problems that students encounter in internationally comparative exams and their future professional life (English, 2006) and being an interdisciplinary subject covering many areas (Cheng, 2001) can be mentioned within the reasons behind this attention.

Researchers working on mathematical modelling emphasized the aspects they worked on while defining mathematical modelling. In some definitions related to 
mathematical modelling, the formation of concepts in mathematics (Özaltun-Çelik \& Bukova-Güzel, 2018) stands out with its relationship with real life and other disciplines. Peter-Koop (2004) expressed mathematical modelling as a complex process that requires creating a mathematical model about real life problems and transferring the results of the model to real life situations. There are also researchers who reveal the relationship between mathematical modelling and other disciplines other than mathematics. For example, BukovaGüzel and Uğurel (2010) express mathematical modelling as a method that represents the research of the solution by conveying the problem situations existing or fictionalized in areas other than the world of mathematics (physics, biology, sociology, politics, art, entertainment, etc.) in the language of mathematics and with mathematical knowledge and approaches. In the mathematical modelling process, it is tried to be expressed in mathematical ways by selecting a subject from the outside of mathematics. Thus, mathematics is utilized to shed light on the subject. When the studies on mathematical modelling are examined, it is not only in mathematics education; it is also seen that modelling has been used in various fields such as mathematics, physics, chemistry, biology and engineering (Hıdıroğlu \& Bukova-Güzel, 2013).

Mathematical modelling has a strong relation with problem solving that is an important subject in mathematics. Mathematical modelling is general term that covers the interest of in many disciplines other than mathematics and involves open-ended and applied problem-solving practices related with real life at all levels of education (Erbaş, Kertil, Çetinkaya, Çakıroğlu, Alacacı \& Baş, 2014). There are multiple cycles such as reaching a solution by using what is given in the problem-solving process, comparing the solution with the real-life situation, developing the solution if it is not enough or developing a different solution (Kertil, 2008). In this respect, mathematical modelling, which is a powerful problemsolving method, includes modelling activities that advance traditional problem-solving views.

Even though mathematical modelling activities look like word problems, they are different from verbal problems. Mathematical modelling activities can be used instead of traditional verbal problems and can be seen as a way of establishing a connection between real world and mathematics (Bukova-Güzel, 2011). According to Pollak (2012), the biggest difference between mathematical modelling and problem solving is that the problem solving does not refer to the real world or even if it does, it begins with an idealized real-life 
situation expressed in mathematical terms, and ends with a mathematical result. In contrast, modelling begins in the "complex" world, after formulating the problem and the phases of problem solving, the modeler returns to the real world where the results are evaluated according to the original context.

Mathematical modelling is seen as an important tool in teaching due to its features such as creating different and effective constructivist learning environments, associating concepts with daily life, and revealing the relationships between different concepts with daily experiences etc. (Blum, 2002). With this tool, students can build a bridge between real life and mathematics. Mathematical modelling contributes to students to learn math topics (Yoon, Dreyfus \& Thomas, 2010), to understand different aspects of mathematics (Lingefjard \& Holmquist, 2005), to recognize their critical and creative aspects while solving original problems and to shape their attitudes towards mathematics (Niss, Blum \& Galbraith, 2007). In addition to the contributions offered to students, modelling activities also support teachers to realize the students' mathematical ideas, skills and abilities more comprehensively. In addition, mathematical modelling activities are seen as an opportunity for mathematics teachers to improve themselves (Lesh \& Doerr, 2003). Due to these achievements, upon understanding the importance of mathematical modelling in mathematics teaching and learning, it has been included in modelling education programs in different countries. In Turkey, mathematical model and modelling are included for the first time and in a comprehensive mathematics curriculum (Ministry of National Education, 2005). It has become even more important with the renewed mathematics education curriculum (Ministry of National Education, 2018). In the MONE (2018), it is emphasized that a classroom environment in which problem-solving processes are carried out, which will enable students to evaluate their mathematical reasoning while expressing their own thinking and reasoning (MONE, 2018). Using modelling eliciting activities (MEAs) including mathematical modeling (English, 2006) will be useful in creating the aforementioned classroom environment.

MEAs are defined as problem solving activities where students create models and explain them by using their mathematical thinking, test and do the arrangements and edits them in order to enable students to benefit from mathematical modelling in complex real-life problems (Eric, 2008). Chamberlin and Moon (2005) state that MEAs help to establish 
interdisciplinary relationships and denoted that students develop skills such as reading comprehension, communicating with peers and explaining their solutions and writing them.

Lesh, Hoover, Hole, Kelly and Post (2000) state that the use of MEAs is effective in teaching and evaluation process as well as their use to reveal students' thoughts for research purposes. It is expressed that when teachers observe their students while working on MEAs and examine the solutions they produce, they can have an idea about their students' conceptual strengths and weaknesses, and they can make their teaching more effective (Lesh et al., 2000). Mousoulides, Christou and Sriraman (2008) state that MEA implementations contribute to students' mathematical literacy, conceptual understanding, social development and metacognition and to teachers' development of pedagogical approaches and teaching practices. From this point of view, MEAs are important tools that can be used for successful mathematics teaching (Tekin-Dede \& Bukova-Güzel, 2014). It is believed that knowing this important tool, which can be used in mathematics teaching, by both mathematics teachers and mathematics teacher candidates, is very significant to find their ways of integrating it into the teaching process, and to develop themselves in designing different MEAs to use in their lessons.

The studies that were done related with MEAs can be listed as follow;

- Ideas about MEAs (Bukova-Güzel, 2011; Şahin \& Eraslan, 2019; Tekin, 2012),

- $\quad$ MEA qualifications (Hıdıroğlu \& Bukova-Güzel, 2013),

- $\quad$ MEA skills (Deniz \& Akgün, 2018; Lingefjärd \& Holmquist, 2005),

- $\quad$ The process of MEA (Eraslan, 2012),

- $\quad$ The hardships confronted during the process of MEA creation (Eraslan, 2012).

There are studies that examined the compatibility of MEAs with design principles (Carlson, Larsen \& Lesh, 2003; Deniz \& Akgün, 2016; Moore, Diefes Dux, 2014; Tekin, 2012; Tekin-Dede \& Bukova-Güzel, 2013; Tekin, Hıdıroğlu \& Bukova-Güzel, 2011). Carlson et al. (2003) converted the bottle problem into an MEA and they concluded that this activity is appropriate with all design principles except it is partially appropriate with the reality principle, which is one of the MEA design principles. Moore and Diefes-Dux (2004) determined that the design of MEAs created in their study with 1st year engineering students was appropriate in all design parameters. In their study, Tekin et al. (2011) found that all MEAs designed by mathematics teacher candidates had the reality, the construct share ability and reusability and effective prototype principles, however, one of the MEAs 
was not totally appropriate for the model construction principle and three of them were inappropriate in the construct documentation principle. Yu and Chang (2011), in a study where mathematics teachers design MEAs, the designed MEAs were appropriate for the reality and model construction principle while they did not satisfy other four principles. In study of Tekin (2012), it was stated that the teachers cared for the reality principle at maximum while they paid the least attention to the prototype principle in the MEAs they designed. Tekin-Dede and Bukova-Güzel (2013) studied the MEA design process named “Obesity Problem" which was created by 4 mathematics teachers and its compatibility with MEA design principles. These MEAs were found completely appropriate for the reality, model reconstruction, and the construct documentation and construct share ability and reusability principle, and were only in compliance with self-assessment principle at some extent. It was determined that the MEAs did not satisfy the prototype principle. Deniz and Akgün (2016) investigated whether the secondary school mathematics teachers created activities compatible with model eliciting principles. It was concluded that all MEAs were totally appropriate in the reality and the construct share ability and reusability principles while they were only partially appropriate in self-assessment principle and the compatibility with the effective prototype principle was not investigated. Tekin-Dede, Hidıroğlu and Bukova-Güzel (2017) analyzed the MEAs created by mathematics teachers in terms of MEA principles. Accordingly, the purpose of this study is the investigation of MEAs prepared by secondary mathematics teacher candidates with regards to MEA design principles.

\section{Theoretical Framework}

Model eliciting activities (MEA) which was first defined by Lesh et al. (2000) are stated as problem solving activities from real life that require to form a mathematical model (Lesh \& Yoon, 2004). Beyond the representation of problem scenarios from real life in MEAs, it is required to develop a model that can be generalized by students in different contexts (Lesh \& Harel, 2003). In addition, MEAs are used as research tools that aim to reveal the thoughts of teachers and students for the solution during implementation (Lesh et al., 2000). At this point, it is necessary to seek for an answer to the questions of how to decide whether an activity is an MEA or what a teacher should consider if he/she wants to design his/her own activity. According to Lesh et al. (2000), teachers or researchers should take into account of the six principles that are shown in Figure 1 while they are creating their own activities or understand whether an activity is an MEA: 


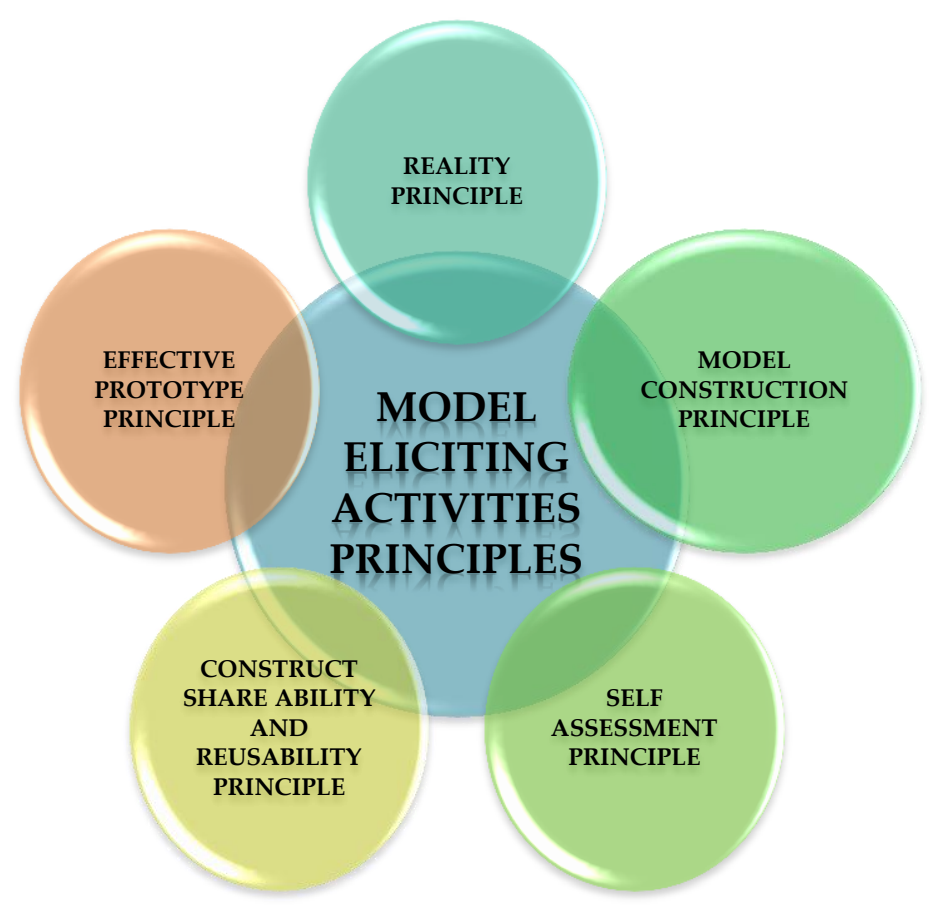

Figure 1. Model eliciting activities principles

The reality principle, which is the first of MEA design principles, the problem situation needs to be a situation that students might encounter in real life (Bukova-Güzel et al., 2016). The most precise way to determine whether an MEA satisfy this principle is to try to reply the question "Can a student come across with such a situation in his/her real life?" (Lesh et al., 2000). In MEAs, students make to develop a model by asking them to help a client or a customer, thus, they are expected to intuit that they are occupied with a real problem.

Model construction principle is that the problem situation requires to construct a model (Bukova-Güzel et al., 2016). Because of this principle, students are expected to create a model in order to reach a solution for a problem (Chamberlin \& Moon, 2005). For the investigation of the presence of this principle, the questions of "Does the given situation require the students to create a model?" or is just answering a situation developed by others enough?" have been asked (Lesh et al., 2000).

In the self-assessment principle, the students are expected to evaluate the suitability and practicality of solutions by themselves without the support or the consent of their teacher (Bukova-Güzel et al., 2016). Therefore, the purpose of a problem that satisfies the self-assessment principle has to be clear and suitable for students' level (Chamberlin \& Moon, 2005). In order to reveal whether an MEA satisfies the self-assessment principle or not, the questions of "Can students evaluate themselves when the answers are needed to be 
improved?", "Will the students realize that they finalize the solution of the problem or will they ask to their teachers if they need to continue to the solution?" has to be answered (Lesh et al., 2000).

In the construct documentation principle, students are required to use as much clear expressions as possible and explain their thoughts with details because they will create model/models for the purpose of helping a client or customer (Bukova-Güzel et al., 2016). While students present their thoughts and solutions, they should document them as the people who encounter the problem can understand (Chamberlin \& Moon, 2005). The survey on the presence of construct documentation principle is provided by answering the question of "Does students' answers given to the problem situation display how they think about this situation clearly?" (Lesh et al., 2000).

One of the MEA design principles is the construct share ability and reusability principle. In this principle, the purpose is not only using models created by the students for a specific situation and purpose but also using them for different situations and purposes at the same time (Bukova-Güzel et al., 2016). The created model can be generalized to similar situations, re-used in similar situations and shared with others. Hereby, students can generate general information that can be useful for other people. The construct share ability and reusability principle searches for answers to the questions of "Is the developed model only useful for the person who developed it or does it provide a way of thinking that can be shared, converted, easily applied and reused?" (Lesh et al., 2000). The effective prototype principle is interested in whether the solution is remembered by students although a long time passes after the implementation (Bukova-Güzel et al., 2016). Even though a long time passes after the solution of the problem, the students should be able to remember the solution when they confront structurally similar situations (Lesh et al., 2000). The effective prototype principle searches for answers to the questions: "Does the developed model create a useful first sample (prototype) for structurally similar situations?", "Can students think of the previous problem in structurally similar situations even a long time passes after the problem solved?" (Lesh et al., 2000). The construct documentation and the effective prototype principles help young mathematicians to learn useful and creative solutions that can be generalized (Chamberlin \& Moon, 2005). 


\section{Method}

This study was designed in the case study, which is one of the qualitative research methods. Yin (1984) defines case study as a research method that is used when: 1) the research is focused on the "how" and "why" questions, 2) the researcher has little or no control over events, 3) the event or phenomenon is studied within its own natural environment, and 4) the connection between the event and real life is not clear enough. Creswell (2013) presents case study as an approach that describes of a situation or reveal its themes in detail. In this respect, it was aimed to investigate the compliance of MEAs developed by secondary school mathematics teacher candidates with the MEA design principles deeply by using case study pattern. In this study, the compatibility of the MEAs developed by elementary school teacher candidates was examined in detail according to the principles mentioned by Lesh et al. (2000). Thus, MEAs developed by teacher candidates were discussed in detail in real environments in terms of the principles. The study was conducted in the scope of Mathematical Modelling Course, which is one of the electives in elementary mathematics education program in the Faculty of Education at a state university in Turkey.

\section{Participants}

The participants were selected with respect to convenience sampling method, which is one of the purposive sampling methods. Convenience sampling is to select the close and easily accessible group of participants in accordance with the purpose of the research. Convenience sampling comparatively costs less and can be perceived as practical and easy. This study was conducted with the 4th grade secondary school mathematics teacher candidates within the elementary school mathematics teacher department in a state university in Agean Region, Turkey. The participants were 28 females and 10 males who were registered to Mathematical Modelling course. The teacher candidates were divided into 8 groups with $4-6$ people.

\section{Data Collection}

The data of the research consist of MEAs developed by secondary school mathematics teacher candidates. The teacher candidates designed an MEA as a group in the last three weeks of the Mathematical Modelling course, performed the solution and reported it. Accordingly, the data of the research were created from documents containing eight 
MEAs designed by the groups and their solution reports. The 14-weeks mathematical modelling lesson where the application took place was planned as indicated in Figure 2.

\begin{tabular}{|c|c|}
\hline Week 1-7 & -Mathematical Modelling \\
\hline Week 8-11 & - Application of Model Eliciting Activities \\
\hline Week 12 & -Designing of Model Eliciting Activities \\
\hline Week 13 & -Solution of Model Eliciting Activities \\
\hline Week 14 & - Reporting Solution of Model Eliciting Activities \\
\hline
\end{tabular}

Figure 2. Data collection process

In between the $1^{\text {st }}$ and $7^{\text {th }}$ weeks of the course given by the researcher, model, modelling, mathematical model, mathematical modelling, mathematical modelling perspectives, mathematical modelling process, mathematical modelling skills and their development, the use of MEAs in teaching and measurement-evaluation stages of MEAs were introduced and their discussions were provided with the help of presentations. The MEAs related publications within the literature were examined (Erbaş et al., 2014; TekinDede \& Bukova-Güzel, 2014). In between the weeks of 8-11, some examples of MEAs were presented. Among these examples, Straw Bale Problem (Borromeo Ferri, 2007), Apartment Problem (Maaß \& Mischo, 2011), Apple Pie Problem (Schukajlow et al., 2012, adapted by Tekin-Dede, 2015) were studied within the groups. The obtained results within groups were discussed in classroom with other groups. In the 12th week, the participants were asked to create a MEA that could be a solution to a problem in the environment in order to establish a relationship with daily life and create awareness. The feedback was given by the researcher about the activity they created within their groups and the creation process of the MEAs was completed. In the $13^{\text {th }}$ week, the groups were asked to solve the MEAs they created. In the $14^{\text {th }}$ week, the designed MEAs and their solutions were reported.

\section{Data Analysis}

In the light of the theoretical framework, the MEA, which is the data collection tool of the research, has been tried to be revealed by document analysis in which extent it satisfies the modelling design principles. Çepni (2007) defines document analysis as a review process which consists of collecting existing records and documents related to the conducted study and encoding them according to the specific norm or system. In this study, the MEAs 
designed by the participants in a certain period of time were examined over a wide period of time with the help of document analysis in order to reveal the status of MEAs compatibility with design principles. This analysis was conducted in the shape of a coding within a wide framework in the classification made by Strauss and Corbin (1990) (cited in Yıldırım \& Şimşek, 2008). In these evaluations, the three categories, which were created by Tekin-Dede et al. (2017), were taken as reference to examine the MEA design principles (See Table 1). In this context, the compatibility of aforementioned principle with each principle was examined in the categories of "totally appropriate", "partially appropriate" and "inappropriate".

Table 1. Definitions of the categories in the evaluation about the principles (Tekin-Dede, Hıdıroğlu \& Bukova-Güzel, 2017)

\begin{tabular}{|c|c|c|c|}
\hline Principle & Completely appropriate & $\begin{array}{l}\text { Partially } \\
\text { Appropriate }\end{array}$ & Inappropriate \\
\hline Reality & $\begin{array}{l}\text { Including realistic aspects } \\
\text { such as the context, the } \\
\text { figures, the data, etc. }\end{array}$ & $\begin{array}{l}\text { Including some aspects } \\
\text { which were not completely } \\
\text { realistic }\end{array}$ & Including unrealistic aspects \\
\hline Model Construction & $\begin{array}{l}\text { Involving model/s } \\
\text { construction peculiar to the } \\
\text { real context }\end{array}$ & $\begin{array}{l}\text { Involving model/s } \\
\text { construction to some extent }\end{array}$ & $\begin{array}{l}\text { Not involving model/s } \\
\text { construction or including } \\
\text { existing model/s }\end{array}$ \\
\hline Self-Assessment & $\begin{array}{l}\text { Including statements about } \\
\text { the necessity to enable self- } \\
\text { assessment }\end{array}$ & $\begin{array}{l}\text { Including deficit statements } \\
\text { about the necessity to enable } \\
\text { self-assessment }\end{array}$ & $\begin{array}{l}\text { Not including statements } \\
\text { about the necessity to enable } \\
\text { self-assessment }\end{array}$ \\
\hline $\begin{array}{l}\text { Construct } \\
\text { Documentation }\end{array}$ & $\begin{array}{l}\text { Including statements } \\
\text { enabling to document } \\
\text { students' thought processes } \\
\text { explicitly }\end{array}$ & $\begin{array}{l}\text { Including deficit statements } \\
\text { enabling to document } \\
\text { students' thought processes } \\
\text { explicitly }\end{array}$ & $\begin{array}{l}\text { Not including statements } \\
\text { enabling to document } \\
\text { students' thought processes } \\
\text { explicitly }\end{array}$ \\
\hline $\begin{array}{l}\text { Construct Share Ability and } \\
\text { Reusability }\end{array}$ & $\begin{array}{l}\text { Enabling to construct } \\
\text { mathematical model/s which } \\
\text { can be used in similar } \\
\text { situations and generalized to } \\
\text { different situation }\end{array}$ & $\begin{array}{l}\text { Enabling to construct } \\
\text { mathematical model/s which } \\
\text { can be used in similar } \\
\text { situations and generalized to } \\
\text { different situation to some } \\
\text { extent }\end{array}$ & $\begin{array}{l}\text { Not enabling to construct } \\
\text { mathematical model/s which } \\
\text { can be used in similar } \\
\text { situations and generalized to } \\
\text { different situation }\end{array}$ \\
\hline Effective Prototype & $\begin{array}{l}\text { Including statements about } \\
\text { the students' remembering } \\
\text { of the problem statement and } \\
\text { constructed models }\end{array}$ & $\begin{array}{l}\text { Including statements about } \\
\text { the students' remembering } \\
\text { of the problem statement and } \\
\text { constructed models to some } \\
\text { extent }\end{array}$ & $\begin{array}{l}\text { Not including statements } \\
\text { about the students' } \\
\text { remembering of the problem } \\
\text { statement and constructed } \\
\text { models }\end{array}$ \\
\hline
\end{tabular}

In order to ensure the reliability of the analysis of the data, the data was analyzed separately by the researcher and an academic working as a faculty member in mathematics education. The MEAs compatible and incompatible aspects with design parameters were determined by the analysis of MEAs compliance to which categories and to what extent were stated. After this statement, the reliability calculation method of Miles and Huberman (1994) was utilized. The reliability of this study was calculated with the help of reliability formula given below, Reliability $=\frac{\text { Agreement }}{\text { Agreement+Disagreement }}$ and determined to be $80 \%$. When the reliability calculations reach over $70 \%$, the study is accepted as reliable by Miles and Huberman (1994). 


\section{Findings}

The findings of the study, in which the MEAs created by the secondary school mathematics teacher candidates were examined according to the mathematical modelling design principles, are given in Table 2.

Table 2. The analyses of the MEAs related to the principles

\begin{tabular}{|c|c|c|c|c|c|c|c|c|c|}
\hline & & $\begin{array}{l}\text { ปี } \\
\frac{0}{0} \\
\tilde{U}\end{array}$ & 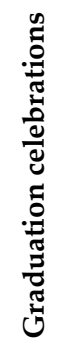 & 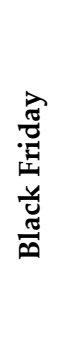 & 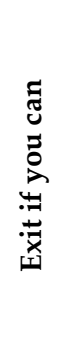 & 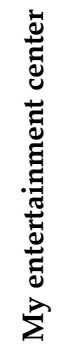 & 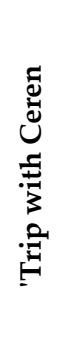 & 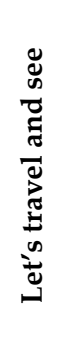 & 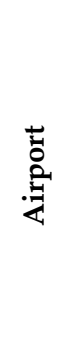 \\
\hline \multirow[b]{2}{*}{ Reality } & CA & $x$ & $x$ & $x$ & $x$ & $x$ & $x$ & $x$ & $\mathrm{X}$ \\
\hline & $\begin{array}{l}\text { PA } \\
\text { In }\end{array}$ & & & & & & & & \\
\hline \multirow{3}{*}{ Model Construction } & CA & & & & & & & & \\
\hline & PA & & $x$ & & & $x$ & $x$ & $x$ & $x$ \\
\hline & In & $x$ & & $x$ & $x$ & & & & \\
\hline \multirow{3}{*}{ Self-Assesment } & CA & & $X$ & $x$ & & $X$ & $X$ & $X$ & $X$ \\
\hline & PA & $x$ & & & & & & & \\
\hline & In & & & & $x$ & & & & \\
\hline \multirow{3}{*}{ ConstructionDocumentation } & $\mathrm{CA}$ & $\mathrm{X}$ & $\mathrm{X}$ & $\bar{X}$ & & & $\mathrm{X}$ & $\mathrm{X}$ & $\mathrm{X}$ \\
\hline & PA & & & & & $x$ & & & \\
\hline & In & & & & $x$ & & & & \\
\hline \multirow{3}{*}{$\begin{array}{l}\text { Construct Share Ability and } \\
\text { Reusability }\end{array}$} & CA & & & & & & & & \\
\hline & PA & & & & & & $x$ & & \\
\hline & In & $x$ & $x$ & $x$ & $x$ & $x$ & & $x$ & $x$ \\
\hline \multirow{3}{*}{ Effective Prototype } & CA & & & & & & & & \\
\hline & PA & & & & & & & & \\
\hline & In & & & & & & & & \\
\hline
\end{tabular}

It is seen from the Table 2 that all MEAs are completely appropriate in reality principle. The participants were not able to create a model that was completely appropriate for model construction principle. Modelling activities created by choosing appropriate contexts from real life included meaningful situations for students' lives. MEAs, all of which were completely appropriate in terms of reality principle, could not show the same compatibility with model construction principle. Especially, the activities were directed towards making calculations rather than modelling because teacher candidates did not include expressions that would lead to the modelling of the problem situation in their activities in terms of the model construction principle. While Graduation Celebrations, My Entertainment Center, Trip with Ceren, Let's Travel and See and Airport were found partially appropriate in terms of model construction principle, Cable Car, Black Friday and 
Exit If You Can were claimed to be inappropriate. According to self-assessment principle, all MEAs were totally appropriate except Cable Car (partially appropriate) and Exit If You Can (inappropriate). In this result, the suitability of created MEAs with the students' mathematical knowledge and skills with respect to their grade levels had an influence. According to construction documentation principle, My Entertainment Center and Exit If You Can were inappropriate although all other MEAs were totally appropriate. MEAs were appropriate due to the fact that the teacher candidates mentioned the possible solutions and thoughts of the students. All MEAs were inappropriate for construct share ability and reusability principle except that Trip with Ceren was partially appropriate. MEAs were not suitable for examination with respect to Effective Prototype principle as MEAs were only analyzed according to the developed and solved MEAs.

Airport and Graduation MEAs are based on basic mathematical operations. It was reported that teacher candidates experienced difficulties in creating models that will lead students to make generalizations. In Cable Car problem, when a complex operational difficulty built on basic operations was created, this problem was thought to be a modelling problem. Although the context of the cable car problem was appropriate, a beautiful fiction from real life was given, and modelling might be required, but it did not support modelling because it was given as a closed-ended problem. Instead, it was a certain solution by using basic operations. In Black Friday MEA, there was not any definitions that would help the students to build a model. In general, they followed a path to choose alternative operations for model eliciting. However, reorganizing the problem in that way "Create such models for all three cases, including buying different numbers of books from different book types so that you can quickly select the most profitable when you enter the number of books received in each model." might be possible to convert the problem into an effective one. In its current form, it was finalized that the activity does not support model eliciting because there were no patterns in the question text that will direct children to form models.

\section{Discussion and Conclusion}

The MEAs of secondary school mathematics teacher candidates were investigated in terms of their compatibility with MEA principles within this study. MEAs were designed for the first time with secondary school mathematics teacher candidates who took mathematical modelling course for the first time. 
All created MEAs were stated to satisfy the reality principle. This result is similar to the results in in the studies (Deniz \& Akgün, 2016; Moore \& Diefes-Dux, 2004; Tekin et al, 2011; Tekin-Dede \& Bukova-Güzel, 2013; Tekin-Dede et al., 2017; Yu \& Chang, 2011) and demonstrated that the analyzed model eliciting activities were totally appropriate for the reality principle. However, Carlson et al. (2003) reached a conclusion that the MEAs were partially appropriate. In the study of Tekin-Dede (2012), the most satisfied principle was reported to be the reality principle. Similarly, in this study, the reality principle was the most satisfied one.

When the MEAs of teacher candidates were analyzed in terms of model constructions principle, five of them were found partially appropriate and three of them was inappropriate. In the studies of Carlson et al. (2003), Moore and Diefes-Dux (2004), Yu and Chang (2011) and Tekin-Dede and Bukova-Güzel (2013), it was seen that the model construction principle was satisfied while in the studies of Tekin, Hıdıroğlu, and BukovaGüzel (2011), MEAs were not appropriate for this principle. Since the MEAs contained no expressions to allow model formation, this principle was not designed to the most suitable level. One of MEAs was partially appropriate according to the self-assessment principle, one of them was inappropriate and rests of the MEAs were found totally appropriate. In the studies of Carlson et al. (2003), Moore and Diefes-Dux (2004), this principle was found totally appropriate while the studies of Tekin-Dede and Bukova-Güzel (2013) and Deniz and Akgün (2016) were only partially satisfied this principle, and the studies of Yu and Chang (2011) were inadequate. The construct documentation principle was partially satisfied by one MEA, found inappropriate for another one and totally satisfied by all other MEAs as it is in selfassessment principle. MEAs, which was also created in the studies of Carlson et al. (2003), Moore and Diefes-Dux (2004) and Tekin-Dede and Bukova-Güzel (2013), completely compiles with the construct documentation principle, Tekin-Dede et al. (2017) and Yu and Chang (2011) was found not to be appropriate for the construct documentation principle. The self-assessment and construct documentation principles were the two most satisfied principles after the reality principle. Considering the MEAs as advanced problem solving, the participants reflected their experience in evaluating themselves continuously in the problem-solving process, evaluating the solution of the activities, expanding the activities, ending the solution of the activity and expressing their opinions clearly. 
The construct share ability and reusability principle was the least satisfied principle. The MEAs were found inappropriate for this principle except one of the MEAs satisfied it partially. In the studies of Carlson et al. (2003), Moore and Diefes-Dux (2004), Tekin-Dede et al. (2017) and Deniz and Akgün (2016), this principle was totally found appropriate. In the study of $\mathrm{Yu}$ and Chang (2011), the construct share ability and reusability principle was not satisfied. This result can be thought as the created models by secondary school mathematics teacher candidates were not designed in a way that they can be used for other situations.

MEAs were not determined in terms of effective prototype principle. To determine if the effective prototype principle is satisfied, it requires that mathematics teacher candidates remember the solution even a long time passes after the solution of the problem or remember the solution in a similar situation (Lesh et al., 2000). In the studies of $\mathrm{Yu}$ and Chang (2011), Tekin-Dede and Bukova-Güzel (2013), Deniz and Akgün (2016), the effective prototype principle was not determined as well. Secondary school mathematics teacher candidates can be given the chance to apply the MEAs designed by them in the classroom to detect the deficient aspects of the MEAs. More MEA implementation and MEA design studies can be done to help secondary school mathematics teacher candidates gain experience with MEAs. Studies can be planned for a longer time in order to investigate the existence of the effective prototype principle.

Acknowledgement

This study was approved by Bartın University SBB Ethics sub-committee with the permission of SBB 2020/41. The data used in this study was confirmed by the researcher that it belongs to the years before 2020 .

Authorship Contribution Statement

Aysun Nüket ELÇİ: Conceptualization, Methodology, Software, Formal Analysis, Data Curation, Writing-original draft.

\section{References}

Blum, W. (2002). ICMI Study 14: Applications and modelling in mathematics educationDiscussion document. Zentralblatt für Didaktik der Mathematik. 34(5), 229-239.

Borromeo Ferri, R. (2007). Personal experiences and extra-mathematical knowledge as an influence factor on modelling routes of pupils. D. Pitta-Pantazi \& G. Philippou (Eds), Proceedings of 
the Fifth Congress of the European Society for Research in Mathematics Education (pp. 2080-2089). Larnaca: Zypern.

Bukova-Güzel, E. (2011). An examination of pre-service mathematics teachers' approaches to construct and solve mathematical modelling problems. Teaching Mathematics and Its Applications, 30, 19-36.

Bukova-Güzel, E. (Ed.). (2016). Matematik eğitiminde matematiksel modelleme araştırmacular, eğitimciler ve öğrenciler için [Mathematical modelling in mathematics education: for researchers, educators and students]. Ankara: Pegem Akademi Yayınları. [Pegem Akademi Publishing.]

Bukova-Güzel, E., \& Uğurel, I. (2010). Matematik öğretmen adaylarının analiz dersi akademik başarıları ile matematiksel modelleme yaklaşımları arasındaki ilişki [The relatinship between pre-service mathematics teachers' academic achievements in calculus and their mathematical modelling approaches]. Ondokuz Mayıs Üniversitesi Eğitim Fakültesi Dergisi, 29(1), 69-90.

Carlson, M., Larsen, S., \& Lesh, R. (2003). Integrating models and modelling perspective with existing research and practice. In R. Lesh \& H. M. Doerr (Eds.), Beyond constructivism: Models and modelling perspective on mathematics problem solving, learning, and teaching (pp. 465-478). Mahwah, NJ: Lawrence Erlbaum.

Chamberlin, S. A., \& Moon, S. (2005). Model-eliciting activities: an introduction to gifted education. Journal of Secondary Gifted Education, 17, 37-47.

Cheng, K. A. (2001). Teaching mathematical modelling in singapore schools. The Mathematics Educator, 6(1), 62-74.

Creswell, J. W. (2013). Nitel araştırma yöntemleri, beş yaklaşıma göre nitel araştırma ve araştırma deseni [Qualitative Inquiry \& Research Design Choosing Among Five Approaches]. Çev. Ed. Bütün M. \& Demir, S. B. Ankara: Siyasal Kitabevi.

Çepni, S. (2007). Araştırma ve proje çalışmalarına giriş [Introduction to research and project studies]. Trabzon: Celepler Matbaacılık [Celepler Printing].

Deniz, D., \& Akgün, L. (2016). Ortaöğretim matematik öğretmenlerinin model oluşturma etkinliği tasarmm prensiplerine uygun etkinlik tasarlayabilme yeterlikleri [The sufficiency of high school mathematics teachers' to design activities appropriate to model eliciting activities design principles]. Karaelmas Eğitim Bilimleri Dergisi, 4(1), 1-14.

Deniz, D., \& Akgün, L. (2018). İlköğretim matematik öğretmeni adaylarının matematiksel modelleme becerilerinin incelenmesi [Investigation of prospective secondary mathematics teachers' mathematical modellling skills]. Akdeniz Ĕ̆itim Araştırmaları Dergisi, 12(24), 294-312.

English, L. D. (2006). Mathematical modelling in the primary school: Children's construction of a consumer guide. Educational Studies in Mathematics, 63(3), 303-323.

Eraslan, A. (2012). İlköğretim matematik öğretmen adaylarının model oluşturma etkinlikleri üzerinde düşünme süreçleri [Prospective elementary mathematics teachers' thought processes on a model eliciting activity]. Kuram ve Uygulamada Eğitim Bilimleri, 12(4), 2953-2968. 
Erbaş, A. K., Kertil, M., Çetinkaya, B., Çakıroğlu, E., Alacacı, C., \& Baş, S. (2014). Matematik eğitiminde matematiksel modelleme: temel kavramlar ve farklı yaklaşımlar Mathematical modeling in mathematics education: basic concepts and different approaches]. Kuram ve Uygulamada Ĕ̆itim Bilimleri, 14(4), 1-21.

Eric, C. C. M. (2008). Using model-eliciting activities for primary mathematics classroom, The Mathematics Educator, 11(1/2), 47-66.

Hıdıroğlu, Ç. N., \& Bukova-Güzel , E. (2013). Matematiksel modelleme sürecini açıklayan farklı yaklaşımlar [Different approaches clarifying mathematical modeling process]. Bartın Üniversitesi Ĕ̆itim Fakültesi Dergisi, 2(1), 127-145.

Hıdıroğlu, Ç. N., \& Bukova-Güzel, E. (2015). Teknoloji destekli ortamda matematiksel modellemede ortaya çıkan üst bilişsel yapılar [Metacognitive structures occuring in mathematical modelling within a technology enhanced environment]. Turkish Journal of Computer and Mathematics Education, 6(2), 179-208.

Kaiser, G., \& Schwarz, B. (2006). Mathematical modelling as bridge between school and university. ZDM - Zentralblatt für Didaktik der Mathematik, 38(2), 196-208.

Kertil, M. (2008). Matematik öğretmen adaylarının problem çözme becerilerinin modelleme sürecinde incelenmesi [Investigating problem solving ability of pre-service mathematics teachers in modeling process]. Unpublished Master Thesis, Marmara Üniversitesi Eğitim Bilimleri Enstitüsü.

Lesh, R., \& Doerr, H. M. (2003). Foundations of a models and modelling perspective on mathematics teaching, learning, and problem solving. In R. Lesh, \& H. M. Doerr (Eds.), Beyond constructivism: Models and modelling perspectives on mathematics problem solving, learning, and teaching (pp. 3-33). Mahwah, NJ: Lawrence Erlbaum.

Lesh, R., \& Harel, G. (2003). Problem solving, modelling, and local conceptual development. Mathematical Thinking and Learning, 5(2 \& 3), 157-189.

Lesh, R., Hoover, M., Hole, B., Kelly, A., \& Post, T. (2000). Principles for developing thought revealing activities for students and teachers. In A. Kelly \& R. Lesh (Eds.), Handbook of research design in mathematics and science education (pp. 591-646). Mahwah, NJ: Lawrence Erlbaum.

Lesh R., \& Yoon C. (2004). Evolving communities of mind: in which development involves several interacting simultaneously developing strands. Mathematical Thinking and Learning, 6(2), 205-226.

Maaß, K., \& Mischo, C. (2011). Implementing modelling into day-to-day teaching practicethe project STRATUM and its framework. Journal Für Mathematik-Didaktik, 32(1), 103131.

Lingefjärd, T., \& Holmquist, M. (2005). To assess students' attitudes, skills and competencies in mathematical modelling. Teaching Mathematics and its Applications, 24(2-3), 123-133.

Miles, M, B., \& Huberman, A. M. (1994). Qualitative data analysis: An expanded Sourcebook. (2nd ed). Thousand Oaks, CA: Sage. 
Ministry of National Education (MONE). (2005). İlköğretim matematik dersi 1-5.sinıflar öğretim programı [Primary school mathematics lesson (grades 1-5) curriculum]. Ankara: Devlet Kitapları Basımevi.

Ministry of National Education (MONE). (2018). Matematik dersi öğretim programı, 1-8.siniflar [Mathematics curriculum (Primary and Secondary School grades 1-8)]. Ankara: Devlet Kitapları Basımevi.

Moore, T., \& Diefes-Dux, H. (2004). Developing model-eliciting activities for undergraduate students based on advanced engineering content. Paper presented at the 34th ASEE/IEEE Frontiers in Education, Savannah, GA.

Mousoulides, N. G., Christou, C., \& Sriraman, B. (2008). A modeling perspective on the teaching and learning of mathematical problem solving. Mathematical Thinking and Learning, 10(3), 293-304.

Niss, M., Blum, W., \& Galbraith, P. (2007). Introduction. In W. Blum, P. Galbraith, H-W. Henn \& M. Niss. (Eds.) (2007), Modelling and Applications in Mathematics Education. The 14th ICMI Study (pp 3-32). New York, NY: Springer Science + Business Media, LLC.

Özaltun-Çelik, A., \& Bukova-Güzel, E. (2018). Doğrusal fonksiyonun öğrenilmesine yönelik tasarlanan matematiksel modelleme etkinliği üzerine çalışan öğrencilerin nicel muhakemeleri [Students' quantitative reasoning while engaging in a mathematical modeling task designed for learning linear function]. Adıyaman Üniversitesi Ĕ̆gitim Bilimleri Dergisi, 8(2), 53-85.

Peter-Koop, A. (2004). Fermi problems in primary mathematics classrooms: Pupils' interactive modelling processes. In I. Putt, R. Farragher, and M. McLean (Eds), Mathematics Education for the Third Millenium: Towards 2010, Proceedings of the 27th Annual Conference of the Mathematics Education Research Group of Australasia (pp. 454461). Townsville, Queensland: MERGA.

Pollak, H. (2012). What is mathematical modelling? In Mathematical Modelling Handbook, edited by Heather Gould, Diane R. Murray, and Andrew Sanfratello, pp. viii-xi. Bedford, Mass.: Consortium for Mathematics and Its Applications (COMAP).

Şahin, N., \& Eraslan, A. (2019). Ortaokul matematik öğretmeni adaylarının matematik uygulamaları dersinde modelleme etkinliklerinin kullanılmasına yönelik görüşler [Middle-school prospective mathematics teachers' opinions on the use of modeling activities at the course of mathematics applications]. Turkish Journal of Computer and Mathematics Education, 10 (2), 373-393.

Tekin, A., Hıdıroğlu, Ç., \& Bukova-Güzel , E. (2011). Examining of model eliciting activities developed by prospective mathematics teachers. Proceedings of the 35th Conference of the International Group for the Psychology of Mathematics Education. 10-15 Temmuz 2011, ODTU, Ankara.

Tekin, A. (2012). Matematik öğretmenlerinin model oluşturma etkinliği tasarım süreçleri ve etkinliklere yönelik görüşleri [Mathematics teachers' views concerning model eliciting activities, developmental process and the activities themselves] (Master's thesis, Dokuz Eylül Üniversitesi, Institute of Educational Sciences, İzmir). Re-trieved from https://tez.yok.gov.tr/UlusalTezMerkezi/. 
Tekin-Dede, A. (2015). Matematik derslerinde öğrencilerin modelleme yeterliklerinin geliştirilmesi: bir eylem araştırması [Developing students' modelling competencies in mathematics lessons: An action research study] Doktora Tezi. Dokuz Eylül Üniversitesi, Eğitim Bilimleri Enstitüsü, İzmir. [Doctoral dissertation, Dokuz Eylül University, Institute of Educational Sciences, İzmir. Retrieved from https://tez.yok.gov.tr/UlusalTezMerkezi/

Tekin-Dede , A., \& Bukova-Güzel, E. (2013). Matematik öğretmenlerinin model oluşturma etkinliği tasarım süreçlerinin incelenmesi: obezite problemi [Examining the mathematics teachers' design process of the model eliciting activity: obesity problem]. İlköğretim Online, 12(4), 1100-1119.

Tekin-Dede , A., \& Bukova-Güzel, E. (2014). Model oluşturma etkinlikleri: kuramsal yapısı ve bir örneği [Model eliciting activities: the theoretical structure and its example]. Ondokuz Mayıs Üniversitesi Eğitim Fakültesi Dergisi, 33(1), 95-112.

Tekin-Dede, A. T., Hıdıroğlu, Ç. N., \& Bukova-Güzel, E. (2017). Examining of model eliciting activities developed by mathematics student teachers. Journal on Mathematics Education. $8(2), 223-242$.

Tural-Sönmez, M. (2017). Matematiksel modelleme problemlerinin yapılandırılması üzerine tasarım tabanlı inceleme: finansal içerik örneği [Design based investigation on construction of mathematical modelling problems: example of financial content]. Journal of Computer and Education Research, 5(10), 218-240. DOI:10.18009/jcer.307314

Tural-Sönmez, M. (2019). Ortaya çıkan modelleme yaklaşımıyla parantez kullanımının anlamlandırılma süreci. Journal of Computer and Education Research, 7(13), 62-89. DOI:10.18009/jcer.499845

Yıldırım, A., \& Şimşek, H. (2008). Sosyal bilimlerde nitel araştırma yöntemleri [Qualitative research methods in the social sciences]. Ankara: Seçkin Yayıncılık [Seçkin Publishing].

Yin, R. (1984). Case study research: design and methods. (3. Ed.). California: Sage Publications.

Yoon, C., Dreyfus, T., \& Thomas, O. J. (2010). How high is the tramping track? mathematising and applying in a calculus model-eliciting activity. Mathematics Education Research Journal, 22(1), 141-157.

Yu, Shih-Yi, \& Chang, Ching-Kuch. (2011). What did Taiwan mathematics teachers think of model-eliciting activities and modelling teaching? In G. Kaiser, W.Blum, R. Borromeo Ferri \& G. Stillman (Eds.), Trends in teaching and learning of mathematical modelling (Vol. 1, pp. 147-156). New York, NY: Springer. 